\title{
Marital Delay in Kashmir a Qualitative Study
}

\author{
Navshad Ahmad Wani ${ }^{1 *}$, Swati Patra ${ }^{2}$ and Rayees Mohammad Bhat ${ }^{3}$ \\ ${ }^{1}$ Department of Psychology, Government Degree College, India \\ ${ }^{2}$ Department of Psychology, Indira Gandhi National Open University, India \\ ${ }^{3}$ Government College for Women, India
}

Submission: November 29, 2017 Published: December 19, 2017

*Corresponding author: Navshad Ahmad Wani, Department of Psychology, Government Degree College, Uri, India; Tel: +919419046265, +919622576025, Email: waninavshad@gmail.com

\begin{abstract}
The present study investigated the trend of Marital Delay among Kashmiri married couples using qualitative approach. The data is collected from the coordinators of Marriage Counseling Centers of three major cities (Baramulla, Sopore and Srinagar) of Kashmir division of Jammu and Kashmir State of India through semi-structured interviews. The Phenomenological design was intended to elicit the perceptions and experience of their counseling services of Kashmiri prospective couples and married couples. The qualitative data was coded and analyzed by Tape Analysis to the voice recorded semi-structured interviews. Marital Delay emerged as the major theme of the study by an in-depth analysis of the responses given by respondents. The three sub themes which emerge from the qualitative analysis are; Completion of Education, Unemployment and Marriage Preparation in financial context. The implications of the present study elucidated in the present paper range from personal growth in marital relationships, mate selection and providing valuable inputs to the psychologists and other professionals involved in marital interventions to the actual understanding of marriage institution in Kashmir.
\end{abstract}

Keywords: Marital Satisfaction; Semi-structured interviews; Marital Delay

\section{Introduction}

Marriage is the only institution in which almost all the people voluntarily enter. Marriage has been understood in very different terms at other times in our history primarily as an economic, social, or political alliance within which satisfaction and romantic love was not particularly important Fowers [1]. Modern times have brought about change in the quality of the marital relationship. With changing generations we find more and more information about what marriage involves and requires. In modern times a lot of challenges have emerged, ranging from deciding towards entering into a love relationship before marriage to be able to learn about protecting and enhancing the marital relationships. This marriage cycle invites a huge scope for investigating the psychological factors in particular and multitude of other factors in general to know what makes and deteriorates this relationship. The main focus of the present study is to identify factors responsible for marital delay in the context of Kashmir under controlled parameters of qualitative research by contacting the coordinators of marriage counseling centers of three prominent cities of Kashmir (viz. Baramulla, Sopore and Srinagar). The coordinators shared their experiences which their clients share voluntarily. It is a challenging task to build a constructive marital relationship in present times and also to identify the variables that predict this outcome of a fulfilling marital relationship. Bellah [2] state that "we seem to have lost our vocabulary for formulating a common understanding of good. Because we have undermined common standards for defining better and worse ways of living, each individual is left to define good for himself/herself".

It becomes so difficult; as the understanding of good and bad has different parameters and their expectations of good in their marriages also differ from individual to individual. Therefore it becomes imperative to make a common ground that majority of couples agree is good for a marital relationship which subsequently becomes the prime factor for marital satisfaction. In United States the average age of brides and grooms declined from the years 1890 to about 1950, today's average first time bride and groom are older than at any other time in U.S. history. But U.S women used to be married by the time they reached age 24. Postponing marriage has become so common that the percentage of women of this age who are unmarried is now more than double what it was in 1970. Another consequence of postponing marriage is that the average age at which U.S. women have their first child is 25.2 , also the highest in U.S. history Mathews [3]. In comparison to the marital trends in U. S, the Kashmir also presents a similar picture. Statistically speaking a major chunk of people of Jammu and Kashmir prefer the status of being unmarried or delay marriage.

As per the 2011 census, 55 per cent of the total population in the state has actually never married, even after attaining a standard marriageable age. This percentage is even higher than the national average of 49 per cent. The percentage of never 
married male populace is 54.7 per cent of the total population, and for females it is 45.12 percent. The number of "never married" persons in Jammu and Kashmir has been on a roll, especially since the outbreak of armed uprising in 1989, and there is ample evidence of its link with the persistent armed conflict, Dabla [4]. National Health Profile 2015, compiled by Central Bureau of Health Intelligence, under Ministry of Health and Family Welfare reported that 25.1 percent of women in J\&K get married in 20s. In states like Andhra Pradesh, this figure stands at 22.8 percent. The all-India figure for women getting married in $20 \mathrm{~s}$ is 23.6 percent. The mean age of marriage for females in $\mathrm{J} \& \mathrm{~K}$ is higher than any other state of India. Love marriages too are on the roll at least five court marriages are solemnized every day in Srinagar alone, Kashmir Headlines: Oct. 24, 2013. The marital delay in Kashmir is a possible reason for Kashmiri peoples' preference for Bengali girls for marriage, Dabla [4]. The prospectus of men to marry in later years are minimal which result into men in Kashmir resort to bringing women from different states of Kashmir especially Bengal. For Bengali women such marriages are almost on no cost which becomes the motivation for them to agree.

Marital satisfaction is much more important to personal well-being than occupational success, religion, housing, or finances combined Bellah [2]. Other innovative researchers on this topic, Wallerstein [5] have extended a tremendous effort to improve the quality of studies done on marriage. The studies thus far are typically not researched on the positive aspects of marriage as supported by Wallerstein [5]. While researchers and clinicians have identified factors that contribute to the failure of marriages, relatively little time has been devoted to finding out what makes good marriages succeed Wallerstein [5]. Therefore, this research became a part of larger effort to create a qualitative understanding of the topic that focuses on the positive aspects of marriage as well as identifying what couples believe make marriages succeed. Marriage is global institution which is found in all the cultures, communities and the countries of world, though its modus operandi differs. Nearly 90 percent of adults marry at least once in their lifetime Schoen Weinick 1993. Yet this part of the globe presents a different picture altogether thus warrants a qualitative investigation.

The marriage rates are high but the divorce rates are also staggering. Studies conclude that there are needs for quality research focused on how marriages succeed rather than their demise. Beirne [6] state that it is sometimes hard even to get people to talk about their good marriages, whatever the cause. It is a phenomenon that needs to be overcome if the engaged and newly married are to benefit from the community's collective wisdom. Many researchers are in agreement that this type of collective wisdom needs to be utilized in the future. Wallerstein [5] in her studies on couples concluded that there is a disproportionate concentration on pathology leaving a striking gap in our knowledge of the family Wallerstein [5]. Numerous studies have been conducted on the age at marriage in the East and south East Asian Countries which are indicative of a fact that the age at marriage has raised significantly Goswami [7] found that the reasons underlying delayed marriage with respect to the 20-24 years age group and the 25-29 years age group differ from culture and the changing patterns of employment and women's' raising status. Lehrer, Chen [8] found strong evidence of the existence of a poor-match effect: women who delay marriage disproportionately make unconventional matches, which are generally associated with high marital instability. The delay in marriage has some potential benefits as well especially for women in terms of wages and lesser employment related challenges, Loughran, Zissimopoulos [9]. Interestingly in certain cultures the importance of education, employment, attainment of maturity and raising the status of women in increasing the age at marriage have positive outcomes. However the age at marriage should be raised to a certain limit beyond which it can hamper marital adjustment of the couple Sathar, Kiani [10].

\section{Methodology}

There are broadly two approaches in research, viz., quantitative research and qualitative research. Quantitative research is one in which one could observe and measure the phenomenon in some way. Such observations and measurements can be made objectively and repeated by other researchers. Measurements indicate how many people behave in a certain way but do not answer "why?" "Qualitative research on the other hand, is a methodological framework which attempts to increase one's understanding of why things are the way they are in the social world." It tells why people act the ways they do. It is concerned with social aspects of the world. Qualitative research is concerned with developing explanations of social phenomena $[10,11]$. Since marriage is a completely psycho-social phenomenon, it becomes imperative to study it qualitatively. The inception of qualitative research grew out of the great desire to probe deep into the social processes for a greater understanding of the social world. In the present study that is "Marital Delay in Kashmir: A Qualitative study" the Phenomenology as a research design was selected. Phenomenology means the study of phenomena. It is a way of describing something that exists as part of the world in which one lives. Phenomena may be events, situations, experiences or concepts. People in general are surrounded by many phenomena, about which though they are aware of, but do not fully understand [12-15].

\section{Study Participants}

\section{Sample}

The individual semi-structured interviews were conducted with the coordinators of the marriage counseling cells in the different cities of Kashmir. "The Humsafar Marriage Counselling Cell Srinagar, the Marriage Counseling Cell of Idarah Falah-eDaareen Baramulla and the Marriage Counselling Cell Sopore" were directly approached with a prior appointment sought from the management for the interview to the coordinators of the cells. Tape analysis was used to record the qualitative data (audio 
records) from the coordinators of marriage counseling cells of Srinagar, Baramulla and Sopore in order to later on analyze the transcribed records of the data [16]. Further in the reporting of the research paper, it was also ensured that the pseudonyms were used to report the responses given by participants in order to guard the identity of the participants.

As illustrated above in Table 1 a total of 3 participants in three individual interviews of the coordinators of Marriage counseling cells [17]. All the three participants (Coordinators of Marital Counseling Centers of Srinagar, Baramulla and Sopore cities of Kashmir) were married. Two participants were from urban localities and one participant was rural. All the participants were educated, professionally competent and above all the members of Kashmiri culture. The age range of participants was between 30-50 years and the duration of their marriage was 1-30 years.

Table 1: Socio Demographic Information of Study Participants.

\begin{tabular}{|c|c|c|c|c|c|}
\hline $\begin{array}{l}\text { S. } \\
\text { No. }\end{array}$ & Respondent & Age & $\begin{array}{c}\text { Duration } \\
\text { of } \\
\text { Marriage }\end{array}$ & $\begin{array}{l}\text { Religious } \\
\text { Background }\end{array}$ & Residence \\
\hline 1 & $\begin{array}{l}\text { Coordinator } \\
\text { Humsafar } \\
\text { Marriage } \\
\text { Counseling } \\
\text { Centre }\end{array}$ & $\begin{array}{c}52 \\
\text { Years }\end{array}$ & 27 years & Muslim & Urban \\
\hline 2 & $\begin{array}{l}\text { Coordinator } \\
\text { Marriage } \\
\text { Counseling } \\
\text { Centre } \\
\text { Baramulla }\end{array}$ & $\begin{array}{c}46 \\
\text { Years }\end{array}$ & 18 Years & Muslim & Urban \\
\hline 3 & $\begin{array}{l}\text { Coordinator } \\
\text { Marriage } \\
\text { Counseling } \\
\text { Centre } \\
\text { Sopore }\end{array}$ & $\begin{array}{c}48 \\
\text { Years }\end{array}$ & 24 Years & Muslim & Rural \\
\hline
\end{tabular}

\section{Tool/Instrument}

The semi structured interviews were used as the instruments of data collection. Semi structured interview method is a qualitative method of inquiry that consolidates a pre-determined set questions that initiate discussion. The discussion provides opportunities for identifying and exploring particular themes. In order to generate and investigate the major and minor themes related with the concept and determinants of marital delay in Kashmir, the interviews questions and the prompts were formulated prior to the execution of the interviews [18-20].

\section{Procedure}

The briefing was given to all the three coordinators of MCCs(the participants of semi structured interviewees). The informed consent was taken from all the participants. The investigator explained the purpose and objectives of the study.

\section{Result and Analysis}

The participants of the semi structured interviews unanimously asserted a strong position for the argument that the first step in understanding the marital satisfaction and adjusting to a healthy marriage is the willingness of the couple to enter a marital relationship. This emerged as a major theme from the data which is named as "avoidance of the delay in marriage". The participants of the present study indicated that desiring for marriage is inevitable and should never be suppressed. During the process of desiring a marriage relationship, couples work toward the goal by possessing a willingness or readiness to marry. "You have to be willing and that's the biggest thing." Muneer (co-coordinator MCC Srinagar) said.The age of marriage is believed to influence marital quality. On late marriages Muneer said, "It is not good from religious and scientific point of view. The delayed marriages have problems like the couples cannot have children (sexual satisfaction) or the delivery complications".

On the similar lines Manzoor (Co-coordinator MCC Baramulla), also said in response to a question; do you think that the age of marriage has changed as some ten years back people married in the age group of 20-30 years but now the marriages are carried out late? "Yes it's true but it is not good from religious and scientific point of view. The delayed marriages have problems like the couples cannot have children or suffer from delivery complications "and delayed marriages are the chief cause of sexual dissatisfaction among the couple and subsequent marital problems."

Mateen (Co-coordinator MCC Sopore) also mentioned the avoidance of marital delay on asking him, "What made you to organize this marriage counseling cell?" Mateen responded, "As I said, that marriages have become very difficult these days. We just want to save a society from the evils as people find it easy day by day to gratify their biological need of sexuality by foul means. This becomes also the reason for the inflation in sex crimes in society. If people will marry at a right age and it will become easy to marry and in turn it will lower the evils in society to spread. We strongly believe that delay in marriage should be avoided. This is the biggest reason for establishing this cell."

\section{Causes of Marital Delay in Kashmir}

The sub category which emerges as we focus on the broad theme of marital delay is causes of marital delay [21-25]. As is evident from a look on the national statistical data on the age at marriage, the youth willfully delay marriage. According to 2001 census, 51 percent of youth attaining marriageable age in $J \& \mathrm{~K}$ are unmarried while as the national figure is 49 percent only. On this, the Coordinator MCC Srinagar (Muneer) responded to this on asking about the reasons of marital delay said,

"Late marriages here have multiple reasons not just one, but three reasons are most prominent in Kashmiri culture. These are Completion of Education, Unemployment and marriage preparation in financial context. One reason is that it is found at our homes that the talk about Nikaah is carried out late. Reason is that they must first complete their education; second that they think that for marriage there should be infrastructure the required money, house construction etc. For attaining those requirements, it takes lot of time to reach that stage of life to be ready for 
marriage. Thirdly unemployment which is very alarming as youth are jobless as there are no industrial units here in Kashmir due to disputed nature of J\&K, which can give job opportunities to youth. and some people consider that for marriage couples should get a level of mental maturity for they think that they are young as yet, in the process they are not able to decide an age for them to marry and they lose that prime age of marriage which become the chief reasons for the delay in marriages".

Muneer mentioned completion of education as a very important factor in the delay of marriages in Kashmir in present times.

"Some people delay marriage for completing education or just saying that they want to complete a task and then marry. There is no guarantee whether they will succeed in their work or not but they shouldn't delay marriage. For this if these kinds of people come forward then we counsel them that your decisions are not right, make them understand what it costs and what its repercussions are. The benefits of delay in marriage are very less in comparison to timely marriage. The impact of your delay in marriage has not only personal repercussions only, but familial and social also. We also feel so contended to help people live productive married lives. Those people who delay for rituals, we counsel them for the betterment of society in general." But what when people don't even think of marriage due to unemployment which is piling up due to squeezing work environment due to disputed nature of the state where the only option available with young prospective couples is government jobs. The government jobs are not sufficient too.

Education and unemployment are closely intertwined in modern society in Kashmir, as a prime factors or causes which delays the marriage in Kashmir. The employment of the men still is considered to be a basic requirement for a marriage to be organized. Moreover, a very significant observation was made by the participants regarding women employment. With the increase in the competitive environment and a preference for a bride who has a job, the education has gained more importance especially in women which become the main reasons for the marital delay [26-30].

On asking if there exists any special reason in the context of Kashmir for this delay in marriage? Muneer Said, "Many reasons are there; one reason is that parents want to celebrate marriage of their children with great enthusiasm or fervor, for which they accumulate money. Second reason is that, the caste and family background the families resort to extremes that is they either do not compromise a bit over caste and family match or they do a huge compromise by joining the poles apart in terms of the caste and family atmosphere (Ifraat o Tafreet). This also becomes a reason for delay in marriage when caste and family atmosphere is given utmost importance. He further added that "the prime reason for such a marriage scenario is due to prolonged political negligence of the state of $\mathrm{J} \& \mathrm{~K}$ which has resulted into marital delay and even drug addiction among youth". The socio-cultural trends like caste, socio-economic status and the communal homogeneity prevail to the extent that some people prefer singlehood over inter caste marriages in Kashmiri culture [3133]. In this context Kashmiri culture is far from the religious and moral directives for marriage and marital traditions. It is also imperative to mention that the caste, economic status and community background are specific to marital traditions and not to the other socio-political fabric of Kashmiri culture.

\section{Conclusion}

Almost all the participants were unanimous in saying that the unnecessary delay in marriage should be avoided as it has biological, social and the psychological consequences. The three prominent reasons for the marital delay in Kashmir which emerge from the qualitative analysis are; Completion of Education, Unemployment and Marriage Preparation in financial context [34]. It was also found that the marital delay is the outcome of women's employment in Kashmir which has actually complicated the marriage market. The caste dynamics is much different in Kashmir than the caste system in India, as caste system in Kashmir is based on occupations and is an obstacle to some extent in marriages across castes. The observations are supported by the studies which propagate education and unemployment as central factors for the marital delay conducted by; Murphy, Sassler, Hofferth, Reid, Mott, Ferre.

In Kashmiri context, on an average, the actual average age of marriage of 31.53 years in men is much higher than the traditional age of 23.6 years. For females, the age of marriage is now 27.8 years, as compared to an expected 20.7 years Dabla [4]. The differences of age of marriage in Kashmiri society are alarmingly higher in comparison to United States, India and elsewhere in the world. This alarming change in the age of marriage is a flashpoint on which this study has been conducted. The question needed a qualitative answer from some experts in the field of marital counseling. Most of the participants viewed late marriages as inevitable under socio-political stir; the valley of Kashmir is passing through. Participants also viewed the reason of late marriages linked to unemployment caused due to disputed nature of the state of J\&K. The political stir in the valley has a lot to explain in terms of delay in marriages in Kashmir because it is linked with the youth of Kashmir usually of marriageable age. "Late marriages is also the offshoot of the prevailing conflict in Kashmir", Amin, Naqshbandi. There is a bulk of literature available against child marriages but timely marriages are also supported by many researchers Grove et al., Asima, Jones, Jones, Gubhaju, Jones, Shen, Visaria and Mackay. The observations of the couples suggest, a consensual age at marriage starts at around 20 years to 28 years in case of women and 25 to 32 years in case of men [35-36].

\section{References}

1. Fowers BJ, Applegate B (1996) Current Psychology 15(3): 197-214.

2. Bellah RN, Madsen R, Sullivan WM, Swindler A, Tipton SM (2007) Habits of the Heart: Individualism and Commitment in American Life. California University Press, USA. 
3. Mathews TJ, Hamilton BE (2005) Trend analysis of the sex ratio at birth in the United States. Natl Vital Stat Rep 53(20): 1-17.

4. Dabla BA (2007) Emergence of Late Marriage in Kashmir. Field Study report; Department Library Department of Sociology and social Work. The University of Kashmir, India.

5. Wallerstein JS, Blakeslee S (1989) Second chances: Men, women and children a decade after divorce. Boston, USA.

6. Beirne P (1997) Rethinking Bestiality: Towards a Concept of Interspecies Sexual Assault. Theoretical Criminology 1(3): 317-340.

7. Goswami B (2012) An investigation into the pattern of delayed marriage in India. The Institute for Social and Economic Change, Bangalore.

8. Lehrer EL, Chen Yu (2013) Delayed entry into first marriage and marital stability: Further evidence on the Becker-Landes-Michael hypothesis. Demographic Research 29(20): 521-541.

9. Loughran DS, Zissimopoulos JM (2004) Are There Gains to Delaying Marriage? The Effect of Age at First Marriage on Career Development and Wages. Rand Working Paper.

10. Sathar ZA, Kiani MF (1986) Delayed Marriages in Pakistan. The Pakistan Development Review 24(4): 535-552.

11. Amin W, Naqshbandi MM (2013) Youth and armed conflict: An analysis of issues faced by youth in Kashmir. Wudpecker Journal of Sociology and Anthropology 1(1): 5-11.

12. Aleem S, Danish l (2008) Marital satisfaction and anxiety among single and dual career women. Journal of the Indian Academy of Applied Psychology 34: 141-144.

13. Bali A, Rajni D, Baru A (2010) Marital Adjustment of Childless Couples. Journal of Social Science 24(1): 73-76.

14. Bano S, Ahmad B, Khan F, Iqbal N, Aleem S (2013) Attachment styles, depression and emotional stability in relation to marital satisfaction among couples. Delhi Psychiatry Journal 16(2): 355-361.

15. Blank RA, Danziger S, Schoeni RF (2007) Working and Poor, How economic and policy changes are affecting low wage workers. Russell Sage Foundation 235-238.

16. Esfahani Fo, Farahbakhsh K, Falsafinezhad MR (2014) The role of Differentiation of Self, Attachment styles, emotional intelligence \& Coping styles in marital satisfaction using path analysis. International Journal of Psychology and Behavioral Research 1(2): 240-247.

17. Eshelman J (1981) The family: An introduction. Allyn and Bacon, Boston, USA.

18. Flowers BJ (1991) His or her marriage-a multivariate study of gender and marital satisfaction. Springer link 'Sex-roles' 24(3): 209-221.

19. Ghanbari-Panah A, Shariff HM, Koochak-Entezar R (2011) The accuracy of emotional intelligence and forgiveness in predicting the degree of satisfaction in marital communications. International Journal of Psychology and Counselling 3(6): 106 -110.

20. Guzman L (2000) Effects of wives' employment on marital quality" NSFH-National Survey of Families and households, Center for Demography and Ecology, University of Wisconsin-Madison 85.
21. Halliday HJ, Geist C, Lucas Amy (2014) "His and Hers: Economic Factors and Relationship Quality in Germany" Journal of Marriage and Family.

22. Horany AA, Hassan SA (2011) Marital Adjustment among postgraduate students at universities in Malaysia. Elixir Psychology 37: 3773-3776.

23. Kalantar kousheh SM, Hasan SA, Kadir RA, Talib MA (2012) Effect of existential issues training on marital satisfaction on Iranian women. The New Educational Review 28(2): 29-38.

24. Kaur T, Sokhey G (2011) personality emotional intelligence and marital adjustment of violent and non-violent couples. Journal of Indian Academy of applied Psychology 37(1): 35-46.

25. Lavner, Justin A Karney, Benjamin R Bradbury, Thomas N (2014) relationship Problems over the Early Years of Marriage: Stability or Change. Journal of Family Psychology 28(6): 979-985.

26. Maciver JE, Dimkpa DI (2012) Factors affecting Marital Stability. Mediterranean Journal of Social sciences 3(1): 437-442.

27. Omolayo BO, Falegan T, Ajila CK (2013) Influence of Job Demand and Employment Status on Marital Conflict and Marital Satisfaction among Women in Ekiti State, Nigeria. Journal of Psychology and Behavioral Science 1(1) 8-18.

28. Pollard, Sara E Riggs, Shelley A Hook, Joshua N (2014) Mutual influences in adult romantic attachment religious coping and marital adjustment. Journal of Family Psychology 28(5): 615-624.

29. Radhika S, Prakash IJ (1987) Factors related to mental health of dual career couples. Journal of Personality and Clinical Studies 3: 131-134.

30. Roosdari AF, Khalatbari J (2014) Effectiveness of Emotional Intelligence Training on Marital Satisfaction among Mothers of Elementary Students in Rasht City of Iran. Journal of Social Issues \& Humanities 2(2).

31. Russell VM, Mc Nulty JK (2010) Frequent Sex Protects Intimates from the Negative Implications of Their Neuroticism. Social Psychological and Personality Science 2(2): 220-227.

32. Shanavas P, Venkatammal PVV (2014) A study on Determinants of Marital adjustment. Online International Interdisciplinary Research Journal 4(4).

33. Sumantra Bose (2005) Kashmir: Roots of Conflict Paths to Peace. Harvard University Press. Massachusetts, USA.

34. Tosang MA, Maleki H, Ahmadimehr Z, Hariri M, Shooshtari M, et al. (2013) Relationship between self-esteem with emotional intelligence and marital adjustment among women. World of Sciences Journal 1(11): 123-130.

35. Whitton, Sarah W, Kuryluk, Amanda D (2014) Associations between Relationship Quality and Depressive Symptoms in Same-Sex Couples. Journal of Family Psychology 28(4): 571-576.

36. Zafar MI, Masood R, Anwar HN (2003) Qualitative Analysis of Marriage Pattern and Family Size: A Study of Urban Punjab. International journal of Agricultural Biology 5(3): 287-291. 
This work is licensed under Creative Commons Attribution 4.0 License

DOI: $10.19080 /$ PBSIJ.2017.08.555728
Your next submission with Juniper Publishers will reach you the below assets

- Quality Editorial service

- Swift Peer Review

- Reprints availability

- E-prints Service

- Manuscript Podcast for convenient understanding

- Global attainment for your research

- Manuscript accessibility in different formats

( Pdf, E-pub, Full Text, Audio)

- Unceasing customer service

Track the below URL for one-step submission https://juniperpublishers.com/online-submission.php 